\title{
The Implementation of Service Learning Strategy as a Means to Produce Competitive Graduates through Vocational Programs: A Case Study in Vocational Program of Administration of Finance and Banking Study Program at Universitas Indonesia
}

\section{Asti Setiawati and Kusnar Budi}

Administration of Finance and Banking Study Program, Vocational Education Program, Universitas Indonesia, Depok, Indonesia

\section{Abstract}

This article discusses about the implementation of service learning strategy as a means to produce graduates from vocational program, in specific from the Administration

Corresponding Author:

Asti Setiawati

asti.setiawati@yahoo.co.id

Received: 8 June 2018

Accepted: 17 July 2018

Published: 8 August 2018

Publishing services provided by Knowledge $\mathrm{E}$

(c) Asti Setiawati and Kusnar Budi. This article is distributed under the terms of the Creative commons Attribution License, which permits unrestricted use and redistribution provided that the original author and source are credited.

Selection and Peer-review under the responsibility of the 2 nd ICVHE Conference Committee. of Finance and Banking Study Program, Universitas Indonesia, who are ready to compete within labor markets. The aim of this study is to explain the process and stages of the implementation of service learning strategy on the learning activities at the study program. The data were derived from primary and secondary sources. Data and information from the primary sources were collected using interviews and observations. Interviews were conducted of the lecturers of the courses/subjects involved in the implementation of service learning method; and also of the students involved in the activities of learning that used learning service strategy. The collected data were analyzed through content analysis method. Results of the study describes three stages in the implementation of service learning, that is, the preparation stage (need assessment and planning), the implementation stage, and the evaluation or reflection phase. The core of service learning is the service activities that are based on the curriculum related to the society, by integrating and collaborating learning activities in the classroom with the activities of serving the community. By the implementation of this strategy, the graduates of Vocational Education Programs of Universitas Indonesia have practical experience of work skills, positive attitude and personal character, as well as practical knowledge.

Keywords: curriculum, service learning, learning activities, work skills

\section{G OPEN ACCESS}




\section{Introduction}

Level of education is one indicators of social prosperity in a country. Moreover, it is also becomes a barometer of fairness and equitable development of a country. According to Indonesia's Law on the National Education System (No. 20/) 2003, education is a conscious and planned effort to create conditions as well as the process of learning that make each participant of education actively develop his or her personal abilities, to have strengths in religious spirituality, self-control, personality, intelligence, and morality; as well as skills for personal, community, and the country required. Education uses by states as a means of investing to improve quality human resources, and therefore, the countries could sustain their development. Development of education in Indonesia is still facing several major problems, such as equitable and enhancing access; improving quality, relevance and competitiveness; as well as governance, accountability, public image, and increase funding, within years ahead (BPS, 2015). Based on Badan Pusat Statistika, several output indicators can be used to evaluate quality of education, are including Literacy Rate (AMH -Angka Melek Huruf), School Enrolment Rate (APS -Angka Partisipasi Sekolah), Gross Enrolment Rate (APK -Angko Partisipasi Kasar), and Net Participation Rate (APM -Angka Partisipasi Murni). Literacy Rate (the ability to read and write, and to communicate with others) in Indonesia, shows that $4.88 \%$ of the population, within the age of 15 years and above cannot read and write on Latin, in 2014. The second indicator, Gross Enrolment Rate describes the individual opportunity to access education. In this case, School Enrolment Rate in 2014 indicates that $1.08 \%$ population of the country, at the age of 5-12 years have not gained their rights of basic education; While based on the Net Participation Rate, there is an increasing trend within each level of education. It proves that there is an increase of citizens' awareness about the importance of education and schooling their children right in time.

The highest level of education in Indonesia is higher education. Higher education plays an importance roles to develop and prepare participants of education to enter and become a member of communities who have academic and professional abilities, and thus can apply, develop, and create science, technology, and arts. Furthermore, higher education has also contributed in developing, disseminating knowledge and science, technology, and arts, as well as to optimize their uses, to improve standard of living and to enrich national culture (UU No. 2 Tahun 1989, PP No. 30 Tahun 1990). 
Law number 12/year 2012 on Higher Education states that there are three types of higher education, which are academic, vocational, and professional education. Academic education is higher education in graduate and or postgraduate programs, which are directed in mastering and developing in a certain branch of science and technology. Vocational education is higher education of diploma program that preparing students to have a certain type of applied skills which can be reached up to the level of applied bachelor program. Whereas, professional education are higher education program after the bachelor's degree, which are preparing students to be ready for jobs with specific requirements of expertise.

Vocational education is an educational institution that plays major roles as producers of human resources with applied skills who are ready to enter working world. In respond to the demand of skilled human resources in labor market, the government is continuously revitalizing vocational education, with the main goal to improve absorption of graduates in working world. The government policies on revitalization of vocational education have also caused by the fact that the number of vocational students in Indonesia is lower than other countries in the world. The efforts to revitalize vocational education will be focused on preparing or designing a new curriculum which is adjusted to the needs of the industries, and to achieve good accreditation, improvement of laboratories, infrastructures, and lecturers (dikti.go.id, 2016).

The focus of revitalization in vocational education relates to the increasing number of graduates who have work competencies that matched with the industries' needs/requirements. This is the primary target of vocational education, to create graduates that ready to work. Therefore, in learning process students or participants of education will receive more practice activities in Laboratories or industries, rather than study theories in the class rooms. Indicators for working readiness of the graduates consist of their skills or work competencies, work attitude: such as discipline, honest, responsible, intelligent, careful, helpful and teamwork abilities (kelembagaan.ristekdikti.go.id, 2017). Study conducted by Widarto (n.d.) explains that in working world, the quality of employees' performance mostly influenced by their attitude and character (28.33\%), physical conditions (26.33\%), knowledge (23\%), and skills (22.3\%). Attitude and character become the biggest component $(28.3 \%)$ in the assessment of the employees' performance quality. This matter proves that the main indicator for the quality of human resources to enter the labor market competition are attitude and character. Based on the above background, this article discusses about the implementation of service learning strategy, as a means to produce graduates from vocational programs which are ready to compete within the labor market. 


\section{Research Methods}

This study used a qualitative case study approach. The method allows an intensive analysis about the process and stages of the implementation of service learning strategy on the learning activities of the students at the Administrative of Finance and Banking Study Program, of Vocational Education Programs, Universitas Indonesia. The data was derived from primary and secondary sources. Data and information from the primary sources are collected by using interviews and observation. Interviews are conducted to lecturers of courses/subjects that involved in the implementation of service learning method; and also to students who involved in the activities of learning that used learning service strategy. The interviews helped the writer to gather inside information about the process within the implementation of the strategy; Interviewees' personal observation, experience, and opinion helped the writer to understand problems and prospect of the implementation of service learning method. The author has conducted observation in the field where the learning activities were held. Valuable data were collected from secondary sources such as organizational records/documents, government regulations, newspapers, books, and the internet. The Collected data were analyzed by content analysis method.

\section{Literature Review}

\subsection{Vocational education program}

According to Law number 12/year 2012 vocational education is higher education of diploma program and applied bachelor program that preparing students with specific applied skills for doing a certain job. Vocational education more emphasis its activities on practical skills through internship programs, company visits, laboratory practices, and other practices to do work. The main role of vocational education is to prepare skilled human resources which is ready to enter the world of work. Accordingly, in their learning process, students directed to develop applied skills, adapted to a certain field of work, and can create job opportunities; whereas the output of its learning process emphasized on work skills to meet industrial demand (vokasi.ub.id, 2017). In addition to work oriented skills, vocational education is also oriented toward culture, empowerment, character formation, and personality. Therefore, it is expected vocational education graduates not only have applied skills only, but also have a high awareness of surrounding environment. 


\subsection{Service learning strategy}

According to Lemieux and Allen (2007) service learning is categorized as a learning model with a pedagogical approach that integrates service to the community with academic learning to form awareness, critical thinking, and creative problem solving on the students. Service learning can also be interpreted as a service activity to a curriculum-based society that integrates and collaborates learning in the classroom with activities serving the community [9]. According to Bringle et al. (2005) service learning implemented to form the experience of learners in providing services to the needs of the community and provide an in-depth understanding of lecture materials through the work practices of service learning activities. In its implementation, service learning integrates curriculum and service components to the community, students who are directly engaged in service learning activities in direct contact with the community [14].

The implementation of service learning method in learning activity will increase the awareness and responsibility of students to the environment. This is because learning with service learning strategy involves students directly in identifying the needs and problems that occur in the community [10]. In learning with service learning method students are required to be sensitive in identifying the needs and problems of society and creative and innovative in creating solutions to the needs and problems that occur in the community. Skills and creativity in problem solving or problem solving is one of the expected results of the application of learning methods of service learning. In addition, service learning also creates giving skills, thus making people who do service learning activities with a whole heart has the power or powerful [8].

\subsection{Implementation stages of service learning strategy}

The results of research conducted by Catherine M. Lemieux and Priscilla D. Allen in 2007 about the evaluation of service learning strategy, states that there are three stages in the implementation of service learning. The first stage is the planning (planning), the second stoge is the implementation (implementation), and the third stoge is the evaluation program (evaluating). Catherine M. Lemieux (2002) adds one early stage before making the planning service learning that is conducting an assessment of the needs and problems that exist in the community. While Nusanti in Jurnal Pendidikan dan Kebudayaan (2014) explains that there are three stages in the implementation of service learning strategy. Service learning begins with preparation, then proceeds to 
the implementotion stoge, and closes with a reflection stoge. Basically, the stages in service learning activities are the same, which is the preparation stage that includes assessment and planning, implementation, and evaluation or reflection stage.

The preparation stage is an important step because learners must assess and process the assessment results into the basis of making program planning. Assessment is a stage to examine the needs and problems that exist in the community (Lemieux, 2012). Planning stage is the early stages of learner and lecturer to recognize and understand the institutions that will be involved in the implementation of the learning process. In the planning phase, the learner and lecturer should also clarify the working relationship before committing to implement the learning process of service learning in the related community (Knee, Powell, \& Causby, n.d.). The core of this preparatory phase is to create a work program plan based on the needs and problems that exist in the community [8]. The following stage is the implementation, in this stage students are guided to run the program plan that has been designed based on the assessment of the needs and problems of society [14]. The last stage is evaluation or refection, according to Nusanti (2014), this stage helps students to evaluate the level of understanding and ability of learners in applying lecturing theory into the work. In addition, the evaluation or reflection phase also helps learners to know the phases that run too fast but not quite right.

\section{Discussion}

Vocational education is a high-level education which its main purpose and role is to create graduates with the practical skills and work skills that are ready to meet the demands of the labor market or related industries. Based on Law no. 12 year 2012 Vocational education is a high-level diploma program that prepares students for jobs with particular applied skills to applied undergraduate programs level. Vocational education becomes one of the spearheads in the strategy of reducing the unemployment rate, as the implication of the learning process in students is not only focused on the type of academic education but more emphasis on the mastery of skills and job skills. It aims to prepare human resources graduates of vocational education ready to work and compete in the labor market. In order to strengthen vocational education, the government issued a policy of strengthening vocational education in Indonesia through Law number 12 of 2012 which confirms that vocational higher education is not only limited to applied bachelor's degree, but also applied master and applied doctorate level. 
The quality of human resources graduates is one indicator of the success of vocational education in improving the skills and abilities of human resources graduates of the vocational program. The main priority of the vocational education program is to produce human resources with quality that they have a high work ethic as a workforce that will strengthen the industry position, which will ultimately strengthen the country's economy (Widarto, n.d.). Moreover, Widarto (n.d.) explains that the result of his survey on 'the opinion of the leadership' found that in the working world the quality of employees performance is greatly influenced by attitude and character (28.33\%), physical condition (26.33\%), knowledge (23\%), Skills (22.33\%). Efforts that can be made by universities and government to adjust the output of vocational program at universities with the needs of industry are to make efforts by revitalizing the vocational education program in Indonesia. One aspect of the focus in revitalizing the vocational education program is to increase the number of graduates who are competent (to do job), ethical, and ready to compete in the country labor market. In order to improve the competence and competitiveness of graduates of vocational education programs, it is stipulated that policy in learning activities will be more practical than classroom theory.

The application of a learning system that integrates lecture theories with field practice requires campus readiness in the transfer of knowledge to learners and creates a link and match between the campuses, in this case the curriculum, with the industrial world (dikti.go.id, 2017). Therefore, with the implementation of policy that integrate theory and practice subjects, it is expected that the graduate students of vocational education programs have skills that match the demand of the labor market. One of the strategies that can be applied in learning activities to improve the skills of learners is provide students with activities that combine and integrate theoretical knowledges with practical experience through the implementation of service learning strategy. Service learning is defined as activities to provide services to communities based on the curriculum; it integrates and collaborates the classroom learning activities with community service activities [9]. The ideal condition of the implementation of service learning is the provision of theory in the classroom, and then the learners are given the opportunity to apply the theory into one job or task.

Service learning is basically a pedagogical approach that integrates aspects of service to the communities with academic learning to shape and improve student awareness, critical thinking, and create problem-solving solutions [14]. According Nusanti (2014), service learning is a learning and teaching strategy that provides opportunities for students to learn to provide services to others based on the theory derived from learning 
in the classroom and the results of assessment of the needs and problems that exist in the communities. Therefore, in the practice of service learning students participate in activities that are designed to meet the needs of the community and provide solutions to the problems faced by the community, then, following stage, student is guided to reflect on service learning activities with the aim of students gain understanding tehadap theory used as the basis in implementing service learning (Bringle et al., 2005). The expected outcomes from the application of service learning are providing students with experience of learning in the real world, service to the community, and increasing student involvement with community members [11]. Implementation of service learning strategy in Financial and Banking Administration Program of Vocational Education at the Universitas Indonesia is conducted by giving conceptual theories through lecturing method at seven initial meetings in the classrooms; then followed by practical activities, where the lecturers assist students to design and implement the work program as a means of evaluating the ability of learners in applying theory into practice work.

Service learning is intended as a means of developing the soul to serve inside the students themselves, so that students are expected not only rich in knowledge but also have a sensitive heart to the surrounding environment [17]. Manifestation of the implementation of service learning strategy, one of them is the improvement of students' soft skills and the formation of the nature and the character of the students that care about their environment. Learning activities with service learning strategies involve the community as a subject of activities as well as a practical laboratory for learners. Implementation of service learning in the Administrative of Finance and Banking, Study Program at Vocational Education of Universitas Indonesia involves four courses or subjects as the theoretical basis which is given by lecturers to learners. The four subjects are Introduction to Administration Science, Applied Statistics, Pancasila, and Bahasa Indonesia. Introduction to Administration Sciences become the basis of the theory for learners (students) to make or design a program planning work. Applied Statistics courses serve as the basis for learners to learn how to implement census, assessment, data recall, data processing, data presentation, and data interpretation. Pancasila courses play an important role as the foundation of the formation of the attitude, behavior, character, and personality of students/learners in everyday life, including during the process of implementing the work program plan in the community. While the subjects of Bahasa Indonesia become the basis for learners in terms of making writing reports about their activities the community. The community that 
involved in the implementation of this strategy is residents of Kelurahan Depok Lama, which are from six Rukun Tetongga.

Based on the results of research by Lemieux and Allen (2007), there are three stages that must be done within the implementation of service learning. The three stages include planning (planning), implementation (implementation), and evaluation program (evaluating). Lemieux (2002) explains, in fact, there is one initial stage before making the planning service learning that is conducting an assessment of the needs and problems that exist in the community. Assessment of needs and problems faced by the community can be done by collecting facts, interviews, and conducting assessment of secondary data. Learning service learning activities require the stages of assessment of needs and problems (need assessment) to determine the needs and problems faced by the community of learning subjects as well as social and physical aspects that require improvement; and therefore, the work program formulated to be the right solution for the problems that exist in the community. Stage to identify the needs and problems of the community (need assessment) implemented by using census techniques with questionnaire instrument, and canvasser method. Under supervision of their lecturers, students conducted this stage. Results from the need assessment used by the students (groups) as information to design program planning.

The first stoge, there are several things that need to be considered in making the planning at first stage. The lecturer and companion students (assistant of lecturers) must recognize and understand the institutions or communities that will be involved in the implementation of the learning process. In addition Knee, Powell, \& Causby (n.d.) suggested that lecturers and student companions need to clarify the working relationship between the college and the community before committing themselves to implement the learning service learning process. It is intended to avoid misunderstanding within the process of implementing the program. Sanders et al., (2003) states that service learning strategy is appropriately applied to new inexperienced students; it aims to prepare students to learn more about social diversity in the community groups involved. Planning of service learning activities should be designed by considering/following results of the assessment of the needs and problems faced by the community, and thus that the public service activities are formulated to be the right solution to the existing problems.

The work plan and problem solving program cannot be solely done by the learners and counselors (assistant of lecturers) based on the assessment result only. However, the process of creating a program plan should involve citizen representatives of the community. It aims to optimize the program plan, an thus that the planned program 
truly addresses the needs and problems faced by the community. According Lemieux and Allen (2007) there are three aspects that must be considered when entering the stage of implementation, one of which is a conflict of interest. In practice the greatest conflict of interest is encountered at the planning stage. Efforts are made to reduce conflicts of interest at the planning stage is by deliberation and discussion between learners with citizen representatives. The process of planning a work program is based on the results of the assessment and the priority of the problem areas to be solved. Learners make the root of the problem scheme, and then create a table of priority needs and problems that will be first resolved. The following step, to reduce the occurrence of conflict of interest, learners must communicate the problem priorities and program plans in discussion forums with representatives of citizens.

The second stage in service learning is the implementation stage. Service learning is basically a service to serve the needs of the community [8]. In the implementation stages, student is guided to run the program plan that has been designed based on the results of the assessment of the needs and problems within society/community [14]. Moreover, research results of Lemieux and Allen (2007) shows that there are several aspects that become the focus of attention in the implementation phase of service learning strategy, such as regulatory aspects to manage conflict of interest, violation of professionalism ethics, and assistance/supervision to unprofessional students in carrying out learning activities. Briefly, the stage of implementation is the phase where learners conduct the work program plan accompanied by the main lecturer. The needs and problems that become the priority of service learning in 2017, in Kelurahan Depok Lama is the empowerment of society in the field of cooperative economy, education, and health. Work program implemented as a cooperative economic development were provide a solution in modernizing the financial records of cooperatives, training and assistance of cooperative financial records, and training of cooperative product marketing strategy. In the field of education, learning activities focuses on empowering and reviving the mosque library, and parenting education workshops; While in the health field, the students cooperated with housewives within which are organized into community movement that main goal is to prosper/welfare the families (called PKK). The students activities program, then attached to Pos yandu and Pos windu program.

The third stoge of the implementation of service learning strategy is the evaluation stage of the whole process. One indicator of successful implementation of service learning is the suitability between programs with the needs and problems faced by the community. The evaluation stage is described as the stage of reflection [8]. In 
this stage, learners are guided to analyze the work or program that has been implemented in the implementation stage. Through this third stage, students are expected to understand the role of materials/theories, concepts and values that are taught in the classroom, and are responsible for applying the knowledge gained in daily life. Eyler and Giles (1999) states that to ensure consistency in the implementation of service learning, lecturers and students must explain and evaluate the relationship between classroom theory and students' experience in providing services to the community. It is intended to know the level of understanding the theories and the abilities to carry out the practice in accordance with the theories studied. The team of lecturers of the Study Program of Finance and Banking Administration at Vocational Education in Universitas Indonesia involved in the implementation of service learning strategy using activities log book as one of the tools to evaluate the performance of learners from the stage of assessment need to evaluation and reporting stage.

Vocational Education Program UI plays an important role in creating skilled, competent, and competitive human resources in the labor market. In order to meet the demand of the Indonesian labor market, graduates of vocational programs are not enough just to have the intelligent Knowledge, Skills and competitiveness only. The graduates must also have the good Attitude and character, positive personality and character that make the graduates of Vocational Education Program can survive and win competition in the labor market. Service learning is one alternative strategies that can be used as a means of character building, personality, and skills for learners. Three stages in the implementation of service learning include the preparation stage (need assessment and planning), implementation, and evaluation or reflection phase. The core of service learning is the service activities that based on the curriculum that related to the society, by integrating and collaborating the learning in the classroom with the activities of serving the community. With the implementation of service learning strategy, it is expected that graduates of Vocational Education Programs of Universitas Indonesia have high work skills and sales value, and have good Knowledge, Skills, Attitude, positive character, and personality.

\section{Recomendations}

Suggestions related to the implementation of service learning strategy in teaching and learning activities of students at the Vocational Education Program in Universitas Indonesia, is that the formation of groups assigned to maintain the sustainability of the programs that have been implemented previously. The lecturers' team need to conduct 
continuously monitoring and evaluation on indicators of successful of the implementation of service learning; and thus can develop assessment about the effectiveness and efficiency of service learning strategy. Lecturers and the team need to develops procedures to monitor and evaluate changes in learners' personalities aspects in terms of attitude, character, personality, and behavior.

\section{References}

[1] Kelembagaan IPTEK \& DIKTI. (2016). Revitalisasi Pendidikan Tinggi Vokasi Menerapkan Sistem 3+2+1. May 14, 2017.

[2] Location: http://kelembagaan.ristekdikti.go.id/index.php/2016/10/31/revitalisasipendidikan-vokasi-menerapkan-sistem-321/

[3] Kementrian Riset Teknologi dan Pendidikan Tinggi Republik Indonesia (2017) Menghadapi Urgensi Pendidikan Vokasi. May 17. Location: http://www.dikti.go.id/ menghadapi-urgensi-pendidikan-vokasi/

[4] Pressreader (2017) Vokasi di Universitas dan Politeknik Sama Pentingnya. March 6, Location: https://www.pressreader.com/indonesia/kompas/20170306/ 281801398752401

[5] Kelembagaan Ristek Dikti. (2017). Revitalisasi Pendidikan Tinggi Vokasi Mendapat Apresiasi Dunia Industri. May 3. Location: http://kelembagaan.ristekdikti.go. id/index.php/2017/02/02/revitalisasi-pendidikan-tinggi-vokasi-mendapatapresiasi-dunia-industri/

[6] Media Indonesia. (2017). Kemenristek Dikti Optimalkan Revitalisasi Pendidikan Vokasi. March 29, 2017.Location: http://mediaindonesia.com/news/read/94622/ kemenristek-dikti-optimalkan-revitalisasi-pendidikan-vokasi/2017-03-02

[7] Kementrian Riset Teknologi dan Pendidikan Tinggi Republik Indonesia. (2017). Tantangan dan Arah Perkembangan Politeknik Indonesia. May 14. Location:http:// www.dikti.go.id/tantangan-dan-arah-perkembangan-politeknik-indonesia/

[8] Nusanti, I. (2014). "Strategi Service Learning: Sebuah Kajian untuk Mengembangkan Kegiatan Pembelajaran". Jurnal Pendidikan dan Kebudayaan, Vol 20 (2), 251- 260.

[9] Furco, Andrew, \& Billig, Shelley. (2001). Service learning: the essence of pedagogy learning. San Francisco: Jossey-Bass. Location: http://books.google.co.id/books. Accessed 15th May, 2017.

[10] Bringle, R. G., \& Hatcher, J. A. (1996). "Implementing service learning in higher education". The Journal of Higher Education, Vol. 67 (2), 221-239. 
[11] Harkavy, I. (2004). "Service-learning and the development of democratic universities, democratic schools, and democratic good societies in the $21^{\text {st }}$ century". New Perspectives in Service Learning: Research to Advance the Field, 3-22.

[12] Sanders, S., McFarland, P., \& Bartolli, J. S. (2003). The impact of cross-cultural service-learning on undergraduate social work students' perception of culture. The Journal of Baccalaureate Social Work, Vol 9 (1), 19-40.

[13] Eyler, J. S., \& Giles, D. E. Jr. (1999). Where's The Learning in Service-Learning? San Francisco: Jossey-Bass.

[14] Lemieux, C. M. \& Allen, P. D. (2007). "Service learning in social work education: the state of knowledge pedagogical practicalities, and practice conundrums". Journal of Social Work Education, Vol 43 (2), 309-325.

[15] Lemieux, C. M. (2001). "Learning contracts in the classroom: tools for empowerment and accountability". Social Work Education, Vol 30, 263-276.

[16] Widarto. (n. d.). Model Pendidikan Vokasi yang Efektif dan Efisien, 1-31.

[17] Osteen, John, \& Joel Osteen. (2013). Living in the Abundance of God. New York: Faith Words

[18] Knee, R. T. (2002). Can service learning enhance student understanding of social work research?. Journal of Teaching in Social Work, Vol 22 (1), 213-225.

[19] Pendidikan Vokasi. (2017). Tentang Vokasi. May 14, 2017. http://vokasi.ub.ac.id/ tentang-vokasi/ 